\title{
One new species of Colocasia Schott (Araceae: Colocasieae) from Arunachal Pradesh in the Eastern Himalayan Region, India
}

\author{
Atek Nangkar, A.P Das and Hui Tag ${ }^{1}$ \\ Plant Systematics and Ethnobotanical Research Laboratory, Department of Botany, Rajiv Gandhi \\ University, Rono Hills, Doimukh-791112, Arunachal Pradesh, India \\ ${ }^{1}$ Corresponding author, e-mail: huitag2008rgu@gmail.com
}

[Received 12.05.2019; Revised 18.06.2019; Accepted 22.06.2019; Published 30.06.2019]

\begin{abstract}
During the search of aroids in Arunachal Pradesh, one aroid plant was recorded from a place about $10 \mathrm{~km}$ away from Boleng town of Siang district, Arunachal, at an altitude of $430 \mathrm{~m}$ AMSL, with geographical location: $28^{0} 18^{\prime} 24.83$ N Longitude and E; 094 $56^{\prime} 86.73$ E Latitude on $27^{\text {th }}$ May 2014. On critical analysis of morphological characters and survey of literature revealed that the collected plant is a hitherto unnamed species of the genus Colocasia Schott. It is named here as Colocasia adiana sp. nov. This new species has resemblance with Colocasia boycena $\mathrm{R}$. Gogoi \& S. Borah and Colocasia fontanesii Schott. The detailed description and illustration were made from living plant materials. The color photograph, reference to Type specimen and some drawings are provided. An artificial Key has been prepared to identify the species of Colocasia found in NE India.
\end{abstract}

Key words: Colocasia adiensis, New species, Arunachal Pradesh, India

\section{INTRODUCTION}

The genus Colocasia Schott, includes 8 accepted species as recorded in www.theplantlist.org and is mainly confined to tropical and subtropical regions of Asia (Li \& Boyce 2010). The genus include some economically significant and widely cultivated species like Colocasia esculenta (L.) Schott but, however, taxonomically the genus is poorly explored. India is the home to several wild species of Colocasia and are abuntant in their wild habitat with numerous highly overlapping forms. Only exhaustive field and laboratory works together can recognize them properly. While exploring Araceae in Arunachal Pradesh, during 2014 - 2018, one plant of the genus Colocasia collected from Boleng in Siang District of Arunachal Pradesh. After critical analysis of morphological characters and study of relevant literatures (Schott 1854; Hooker 1893, 1900; Karthikeyan et al. 1989; Mayo et al. 1997; Li \& Wei 1993; Li \& Long 1998, 1999, 2000; Cao \& Long 2003; Long \& Liu 2001; Yin et al. 2004; Cai et al. 2006; Li \& Boyce 2010) the plant was recognized as a hitherto unidentified species of the genus. Now, the the plant is described and named here as Colocasia adiana A. Nangkar, A.P. Das \& H.Tag, - an addition to the aroid flora of the world.

\section{MATERIALS AND METHODS}

During survey for aroids in Arunachal Pradesh in May 2014 one unknown species of Colocasia Scott was collected from a place about $10 \mathrm{~km}$ from Boleng town in the Siang District of Arunachal Pradesh. The specimen was processed into mounted herbarium sheets following Jain \& Rao (1977) and Croat (1985). The freshly collected whole plants or plant parts were also brought to Plant Taxonomy Laboratory of Rajiv Gandhi University for 
detailed observation of its morphological characters. Type specimens will be deposited in ASSAM and HAU (Herbarium of the Botany Department, Rajiv Gandhi University) after its publication. For photography a Cannon Power Shot SX500 IS camera was used.

\section{TAXONOMIC TREATMENT}

Colocasia adiana A.Nangkar, A.P. Das \& H.Tag, sp. nov.

The new species resembles Colocasia fontanesii Schott (a dark purple species commonly grown as ornamental) but can be readily distinguished by its wild occurrence with purple cataphyll and densely hairy male flower zone, though both the species lacks an appendix. The new species Colocasia adiana is also closely resemble with Colocasia boycena R. Gogoi \& S. Borah (Gogoi \& Borah 2013) and the morphological different of the species from this are given below in tabular form (Table 1).

Type: INDIA, Arunachal Pradesh, Siang district, Boleng, Atek Nangkar 118, dated 27.05.2014 (Holotype: ASSAM; Isotype: HAU). [PLATE I, A - K]

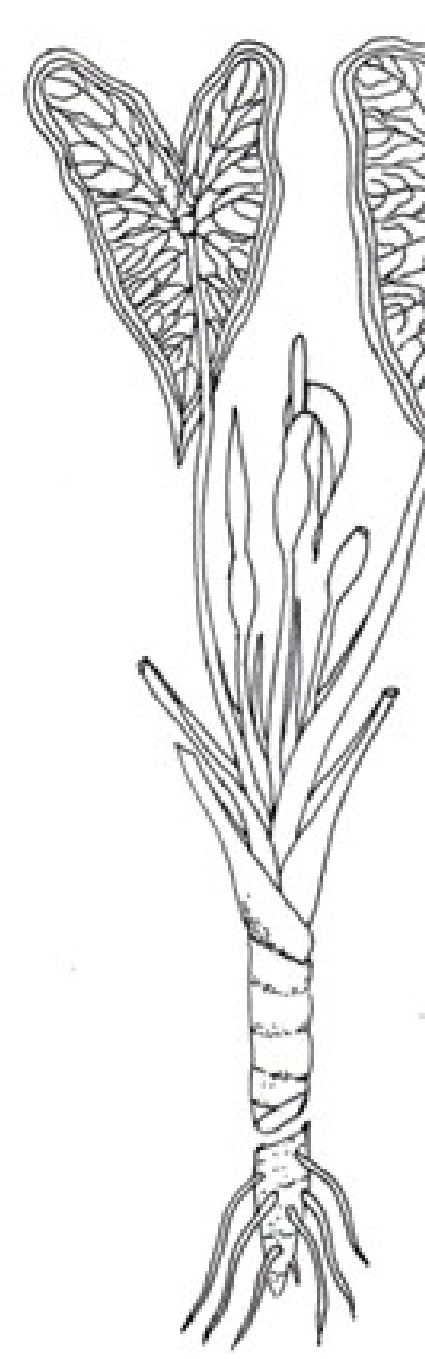

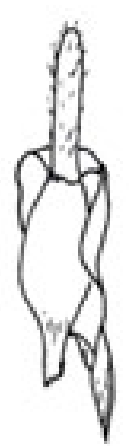
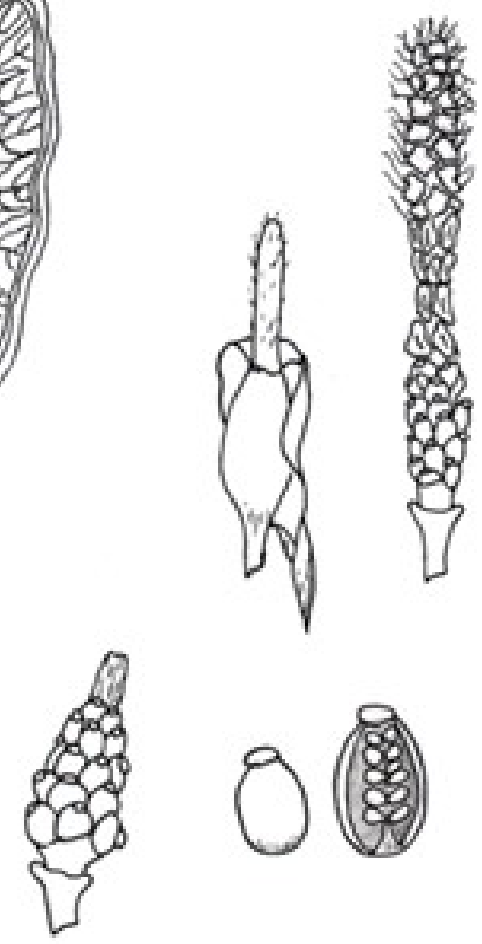

Figure 1. Colocasia adiana. A. Plant habit with inflorescence; B. inflorescence with reflexes spathe; C. spadix, female lower part, sterile middle part, Male upper part, no appendix; D. Fruit; E. ovary \& V.S. of ovary showing ovules. 


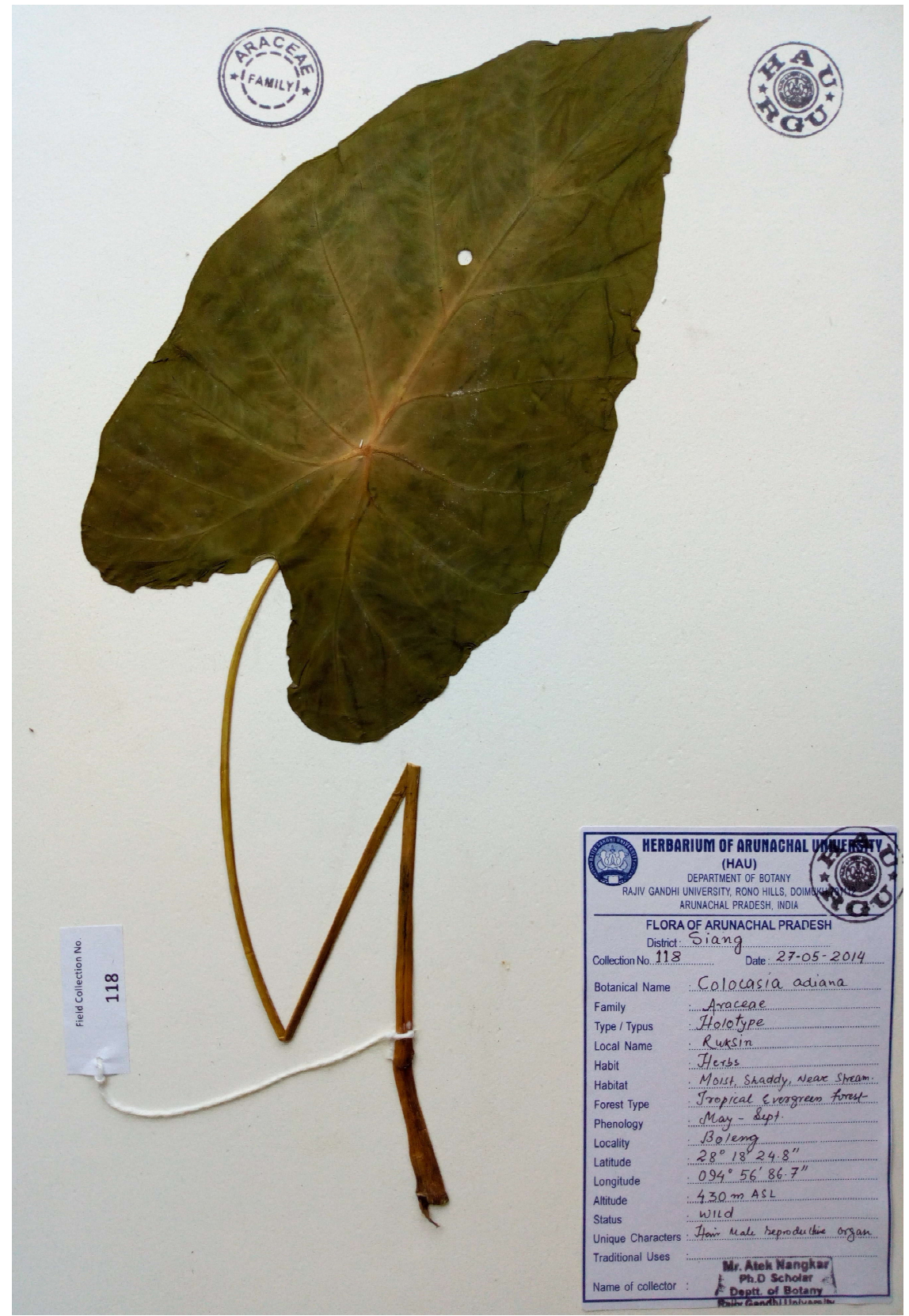

Figure 2. Colocasia adiana, Holotype, Atek Nangkar 118

Description: Herb, medium to somewhat robust. Corm terete, medium, generally erect, slightly decumbent when old, $15-40 \mathrm{~cm}$ long, $4-8 \mathrm{~cm}$ in diameter; roots many, thick, terete, white. Offsets small. Leaves 6-16; petioles $65-91 \mathrm{~cm}$ long, cannulate, dark purple to dark green, cannulate furrow green, purple lining at margin, sheathed at base; leaf blade saggitate, acute to acuminate, $46-64 \mathrm{~cm}$ long, $20.5-36 \mathrm{~cm}$ in diameter, glossy, dorsally dark green, ventrally pale green, white spot at the dorsal junction of petiole, lateral veins $5-7$, raised ventrally, impressed dorsally, marginal lines (vein 
162 New species of Colocasia from Arunachal Pradesh
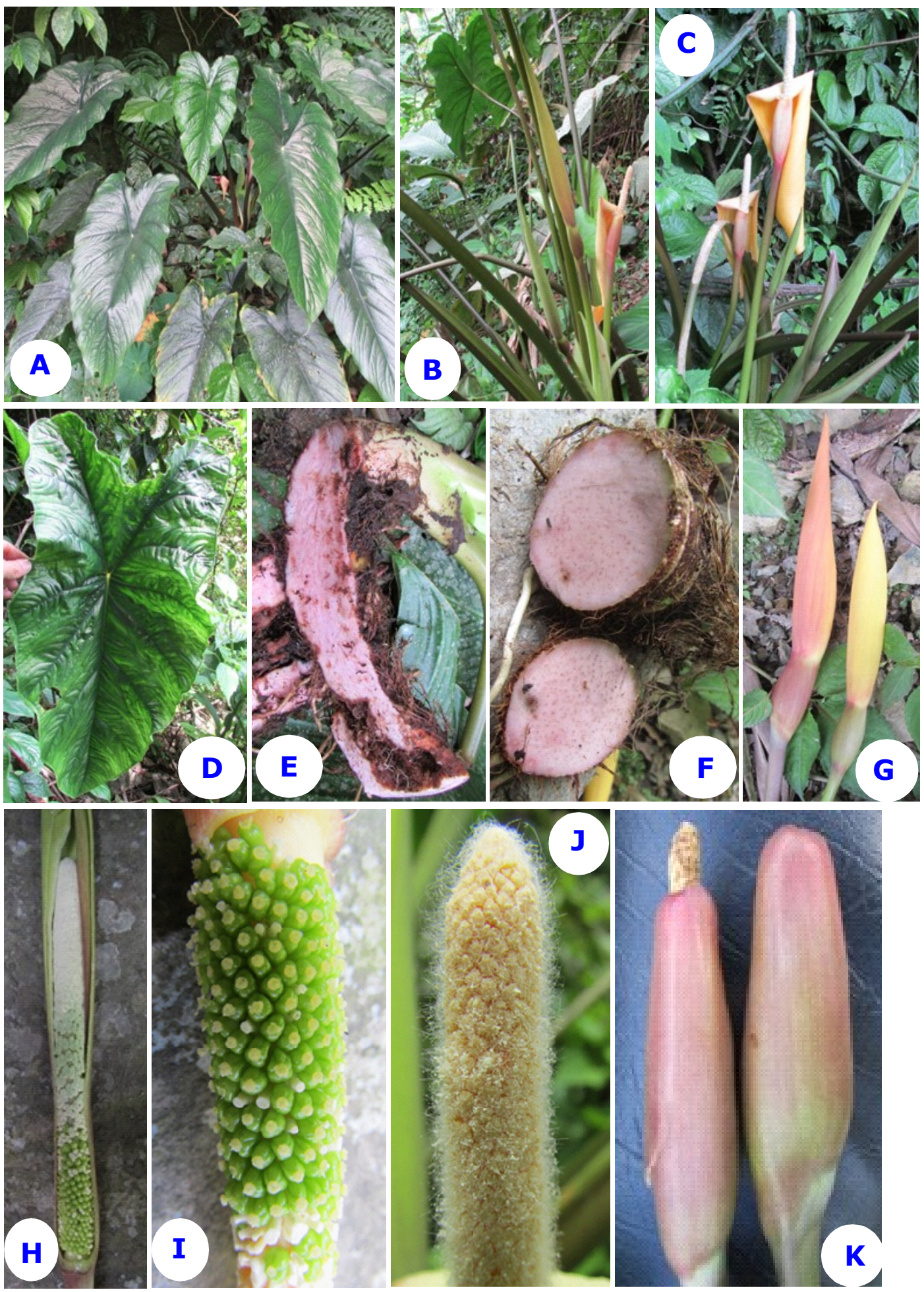

PLATE I: Colocasia adiana: A. Plant habit in in-situ; B \& C. Plants with young \& old inflorescence in in-situ condition; D. Closed view of leaves morphology; E \& F. V.S \& T.S of corms; G. Inflorescence; H. V.S of inflorescence; I. Female zone; J. Male zone with white hairs; K. Fruit. 
Table 1. Morphologically distinguishable characters between Colocasia adiana sp.nov. and colocasia boycena R. Gogoi \& S. Borah.

\begin{tabular}{|c|c|c|}
\hline Characters & Colocasia boycena & Colocasia adiana \\
\hline $\begin{array}{l}\text { Habit \& } \\
\text { habitat }\end{array}$ & Wild, in massive colony & $\begin{array}{l}\text { Wild, medium to somewhat robust, } 1.5 \\
\mathrm{~m} \text { high, no colony formation, } 1-3 \\
\text { plants in small clusters }\end{array}$ \\
\hline Corm & $\begin{array}{l}\text { Sub-cylindric, errect to slightly } \\
\text { horizontal, } 11-17 \mathrm{~cm} \text { long, } 4 \\
-6 \mathrm{~cm} \text { in diameter }\end{array}$ & $\begin{array}{l}\text { Brown outside, inside purple white, } 10 \\
-22 \mathrm{~cm} \text { long, } 4-7 \mathrm{~cm} \text { in diameter, } \\
\text { offsets many }\end{array}$ \\
\hline Stolon & Stoloniferous & Stolons absent, but with offsets \\
\hline Petiole & $\begin{array}{l}\text { Glaberous, green, } 47-82 \mathrm{~cm} \\
\text { long, } 0.8-1 \mathrm{~cm} \text { wide }\end{array}$ & $\begin{array}{l}91 \mathrm{~cm} \text { long }(52 \mathrm{~cm} \text { plus canulated part } \\
39 \mathrm{~cm}) \text {, purple brown to purple green, } \\
\text { cannulated, inside green, purple line at } \\
\text { top }\end{array}$ \\
\hline Leaf blade & $\begin{array}{l}\text { Leaves } 3 \text { - } 6 \text {; leaf-blade ovate- } \\
\text { cordate, sagittate-cordate, } \\
\text { purple at petiole junction, with } \\
\text { purple lining along the leaf } \\
\text { margin }\end{array}$ & $\begin{array}{l}\text { Leaves } 6-16 \text {; leaf-blade sagittate, } \\
\text { acute to acuminate, green to dark } \\
\text { green, somewhat wrinkle, marginal } \\
\text { vein collectors two; white at petiole } \\
\text { junction }\end{array}$ \\
\hline $\begin{array}{l}\text { Inflorescence, } \\
\text { peduncle }\end{array}$ & $\begin{array}{l}\text { Inflorescence 1; peduncle } \\
\text { green }\end{array}$ & $\begin{array}{l}\text { Inflorescence } 3-6,34-48 \mathrm{~cm} \text { long; } \\
\text { peduncle dark purple, base pale green }\end{array}$ \\
\hline Spathe & Tube green, limb yellow & $\begin{array}{l}\text { Limb } 26 \mathrm{~cm} \text { long, } 9 \mathrm{~cm} \text { wide, reflexed, } \\
\text { light green at young; tube } 5.5 \mathrm{~cm} \text { long, } \\
3 \mathrm{~cm} \text { in diameter, purple to yellow; } \\
\text { tube purple }\end{array}$ \\
\hline Spadix & Sessile, $7 \mathrm{~cm}$ long & $15 \mathrm{~cm}$ long; stipe short, $0.5 \mathrm{~cm}$ long \\
\hline Female zone & $\begin{array}{l}\text { Whitish green, } 2 \mathrm{~cm} \text { long, } 0.8 \\
\mathrm{~cm} \text { in diameter }\end{array}$ & $\begin{array}{l}\text { Green, } 2.5-4 \mathrm{~cm} \text { long, } 1-1.5 \mathrm{~cm} \text { in } \\
\text { diameter; stigma sessile, white, sticky, } \\
3 \text { lobed }\end{array}$ \\
\hline Male zone & $\begin{array}{l}\text { Creamy, white hairy, } 2.5 \text { long, } \\
0.8 \mathrm{~cm} \text { in diameter }\end{array}$ & $\begin{array}{l}\text { Creamy, yellow, white hairy, } 9 \mathrm{~cm} \\
\text { long, } 1.3 \mathrm{~cm} \text { in diameter }\end{array}$ \\
\hline Cataphyll & On stolons, pink & $\begin{array}{l}\text { At the inflorescence base, purple, } 42 \\
\mathrm{~cm} \text { long, } 3.7 \mathrm{~cm} \text { in diameter }\end{array}$ \\
\hline
\end{tabular}


collectors) two. Inflorescence 3 - 6. Peduncle terete, shorter than petiole, $34-48 \mathrm{~cm}$ long, $0.7-1.1 \mathrm{~cm}$ in diameter, base dark green, distal part dark purple, reddish pink or reddish purple near tube. Spathe constricted between tube and limb; tube $5.5 \mathrm{~cm}$ long, 3 $\mathrm{cm}$ in diameter, dark purple or reddish purple, light green at young; limb $26 \mathrm{~cm}$ long, 9 $\mathrm{cm}$ in diameter, reflexed, light green at young turns purple, both surfaces yellow, oblong to lanceolate, acuminate. Spadix much shorter than spathe, $15 \mathrm{~cm}$ long; stipe short, $0.5 \mathrm{~cm}$ long; female zone green, cylindric to sub-cylindric, less inter-stiller staminodes, whitish, those seem to be unfertilized ovaries; ovaries green, obovoid to ovate, stigma sessile, translucent white, jelly like, sticky, sterile zone between female and male zone yellowish white (creamy); Male zone $9 \mathrm{~cm}$ long, $1.3 \mathrm{~cm}$ in diameter, creamy yellow with white hairs; synandria $4-8$ androus, creamy with white hairs; appendix absent. Berries green, many seeded.

Etymology. This plant was collected from an Adi tribe dominated area, so the specific epithet is given in honour of this community of people in Arunachal Pradesh.

\section{Key to the species of Colocasia Scott in NE India}

1a. Appendix present and more than $2 \mathrm{~cm}$ long ...................... 2

1b. Appendix absent or highly reduced, less than $1 \mathrm{~cm}$ long ............ 5

2a. Young leaves pinkish, blade $42-75 \times 40-75 \mathrm{~cm}$; spathe pink, tube reddish. purple; spadix deep pink, appendix triangular conic .......................... C. dibangensis

$2 b$. Young leaves whitish green or pale green, blade smaller than $10-45 \times 10-35 \mathrm{~cm}$; spathe yellow or greenish white, or slightly purplish apically ( C. fallax), tube green; spadix yellow or pale yellowish-green, appendix narrowly conic to cylindric and narrowly conic 3

3a. Plant tuberous or rhizomatous, up to $100 \mathrm{~cm}$ tall; spathe dull yellow, spreading and open flat, not revolute; infructescence erect

C. esculenta

3b. Plant stoloniferous, less than $75 \mathrm{~cm}$ tall; spathe bright yellow, not spreading, revolute; infrutescence pendent

4a. Leaves with dark patches between primary lateral veins; female and male zones contiguous ....................................................... affinis

4b. Leaves usually concolourous green; female and male zone separated by a zone of synandrodes

C. fallax

5a. Plant robust, up to $225 \mathrm{~cm}$ tall; petiole and peduncle deep purple-red; spathe c. $25 \times 11$ $\mathrm{cm}$; appendix reduced, less than $1 \mathrm{~cm}$ long

C. fontanesii

5b. Plant small to medium, less than $130 \mathrm{~cm}$ tall; petiole green or light purple reticulate; spathe less than $17 \times 7 \mathrm{~cm}$; appendix absent 6

6a. Leaf margin with purple lining; purple spot at ventral junction of petiole; venation impressed; synandria with white hairs

C. boyceana

6b. No purple lining and spot on leaves; venation raised; synandria without hairs .7

7a. Male part densely white hairy; lamina wrinkle, white at dorsal junction of petiole, tube purple

7b. Male part not densely hairy; lamina not wrinkled adiana

8a. Basal lobes of leaf obtuse; petiole green; spathe tube c. $2.5 \mathrm{~cm}$; synandria stellately crenate; sterile zone c. $1.2 \mathrm{~cm}$ long C. manii

8 b. Basal lobes of leaf usually acute; petiole light purple reticulate; spathe tube c. $5.5 \mathrm{~cm}$; synandria polygonal; sterile zone c. $3 \mathrm{~cm}$ long C. lihengiae 
Note: The present work established the existence of another wild species of the genus Colocasia Schott. The Indian distribution of the genus is much wide, from the Himalayan range to Western Ghats and also extended to neighboring countries like China, Bhutan, Myanmar, Bangladesh etc. The rich but poorly explored flora of Arunachal Pradesh in North East, India is expected expose many more novel elements. Different species of Colocasia now growing in NE India are $C$. adiana, $C$. esculenta, $C$. boyceana, $C$. affinis, $C$. dibangensis, C. fallax, C. fontanesii, C. manii and C. lihengiae (Gogoi \& Borah 2013). The existence of so many species in this region indicates that the genus has a long and complex history in the Himalayan region with active processes of differentiation and evolution. It is now essential to explore the region intensively and that may lead to the discovery of new species of Colocasia and, ofcourse, for many other taxonomic groups.

The Colocasia adiana sp.nov, is a wild species, that does not form a colony, grwing withhardly $1-4$ individual plants in the vicinity. It prefers to grow in tropical forests, upto an altitude of $600 \mathrm{~m}$ AMSL. The species is restricted to few districts only with IUCN status not evaluated.

\section{Acknowledgements}

The first author is thankful to the Center with Potential for Excellence in Biodiversity, RGU for financial assistance and to the Department of Botany, Rajiv Gandhi University for necessary facilities for carrying out this research work.

\section{LITERATURE CITED}

Cai, X.-Z.; Long, C.L. \& Liu, K.-M. 2006. Colocasia yunnanensis (Araceae), a new species from Yunnan, China. Ann. Bot. Fenn. 43: $139-142$.

Cao, L.-M. \& Long, C.L. 2003. Colocasia bicolor (Araceae), a new species from Yunnan, China. Ann. Bot. Fenn. 40: 283 - 286.

Croat, T.B. 1985. Collecting and preparing specimens of Araceae. Ann. Miss. Bot. Gard. 72: $252-258$.

Gogoi, R. \& Borah, S. 2013. Two new species from Arunachal Pradesh, NE, India, Gard. Bull. Singapore 65(1): 27 - 37.

Hooker, J.D. 1893. Araceae. In: The Flora of British India, 6: 490 - 558. L. Reeve \& Co., London.

Hooker, J.D. 1900. Colocasia antiquorum var. fontanesii. Curtis's Bot. Mag. 126 (ser.3.v.56): t. 7732.

Jain, S.K. \& Rao, R.R.1977. A Handbook of Field and Herbarium Methods. Today \& Tomorrow's Printers and Publishers, New Delhi.

Karthikeyan, S.; Jain, S.K.; Nayar, M.P. \& Sanjappa, M. 1989. Monocotyledonae. In: Florae Indicae Enumeratio. Botanical Survey of India, Calcutta. P. 10.

Li, H. \& Boyce, P.C. 2010. Colocasia. In: Flora of China 23. Beijing: Science Press; St. Louis: Missouri Botanical Garden Press. Pp. 73-75.

Li, H. \& Long, C.L. 1998. A preliminary revision of Araceae in China. Acta Bot. Yunnan. Supp. 10: $12-23$.

Li, H. \& Long, C.L. 1999. A new species of Colocasia (Araceae) from Mts. Gaoligong, China. Feddes Repert. 110: 423 - 424. 
166 New species of Colocasia from Arunachal Pradesh

Li, H. \& Long, C.L. 2000. Colocasia gongii (Araceae), a new species from Yunnan, China. Feddes Repert. 111: $559-560$.

Li, H. \& Wei, Z.X. 1993. Colocasia heterochroma, a new species of Colocasia from Araceae. Acta Bot. Yunnan. 15: 16 - 17.

Long, C.L. \& Liu, K.M. 2001. Colocasia lihengiae (Araceae; Colocasieae), a new species from Yunnan, China. Bot. Bull. Acad. Sin. 42: 313 - 317.

Mayo, S.J.; Bogner, J. \& Boyce, P.C. 1997. The Genera of Araceae. Royal Botanic Gardens, Kew, U.K.

Schott, V. 1854. Pflanzenskizzen. In: Oesterreichischesbotanisches Wochenblatt 4(51): $409-410$.

Yin. J.-T.; Li, H. \& Xu, Z.-F. 2004. Colocasia menglaensis (Araceae), a new species from southern Yunnan, China. Ann. Bot. Fenn. 41: 223 - 226. 